\title{
Role of Government in Challenges of Agricultural Education for Child and Economic Development
}

\author{
Celestine O.Emeh \\ Department of Agricultural Education, Ebonyi State College of Education, Ikwo-Ebonyi State, Nigeria
}

\section{Doi:10.5901/mjss.2014.v5n26p72}

\section{Abstract}

The growth, development and progress of any nation entirely depend on its ability to actually manipulate its human and agricultural resources by ensuring adequate scientific, technological and skillful knowledge in agricultural education of higher institutions to meet up with the increasing challenges in our nation. The major problem affecting the higher institutions ability to meet the nations need for agricultural education graduates is the lukewarm attitude of the government to promote the course of agricultural education. The skill and knowledge of agricultural education help the child to create employment and contribute more meaningful to the nation's economic development. This paper therefore focuses on the role of government on challenges of agricultural education for child and economic development. This paper among others discussed the link between agricultural education and human and economic development. The paper also among others suggested evolving agricultural education and training system model that will provide coordinated efforts of agricultural institutions to better tackle challenges as they emerge.

Keywords:Agricultural Education, challenges, government, economic, development

\section{Introduction}

The Ashby commission set up in 1959 by the Federal Government noted with dismay that although agriculture was the man stay of Nigeria yet agricultural Schools had failed to attract bright Young men with school certificate. The commission among other things recommended the establishment of more universities in the country to offer courses in Engineering, Medicine, Law, Commerce and Agriculture etc.

The out come of the commissions recommendation led to the establishment of the Universities in Nsukka, Zaria, Ife, Benin etc. These Universities, offer courses in agriculture and related disciplines.

The commission noted that at the graduate level of agriculture, the prime need was for research both fundamental and applied and that imperative improvement in the agricultural economy of the country could not be realized unless there were also agricultural education at all levels.

What may be seen as the climax of agricultural education in Nigeria is the establishment of University of agriculture at Makurdi, Abeokute and Umudike to produce high level manpower in different areas of agriculture. This is in addition to other Universities and other tertiary institutions in the country with faculties of agriculture.

Today, various colleges of education in the country turn out agricultural science teachers to teach pre-vocational agricultural in the junior secondary schools. There is no state in the country today that does not have one or more colleges of education located in it [Okorie 2001] this augurs well for the training of the desired teachers of agriculture.

Undoubtedly, the Ashby commission made an important land mark in the development of agricultural education in higher institution in the country, that there are few Universities in the country with department of agricultural education whose primary objective is the training of students for secondary schools as well as in other higher institutions of learning. The lukewarm attitude of the government toward agricultural education gave rise to among others, food insecurity, environmental degradation, societal youth unemployment and the most inadequate agricultural teaches, for without the agricultural teachers, the younger generations may continue to develop apathy for agriculture as a profession.

\section{Concept of Agricultural Education}

According to Osinem [2008], agricultural education is a process of imparting knowledge, skill and attitude in agriculture to the learner at any level. Obibuaku [1983] describes it as education and training given in agriculture from primary school through secondary school and special schools to the University. Agricultural education is offered at all levels of education ranging from home to the school and the community. Agricultural education provides learners with sound academic 
knowledge and skill as well ample opportunity to apply this knowledge in all aspect of agro business such as planning, management, safety, finances and leadership. It equips learners to be self employed in industry, foreign services, business or industry and as agricultural educator.

\section{Objectives of Agricultural Education}

In order to prepare learners for successful course in agriculture, Osinem 2008 stated that agricultural education focuses on providing learning experiences that will enable them to:

1. Demonstrate desirable work ethics and habits.

2. Apply the basic agricultural competencies and background knowledge in Agriculture and related occupations.

3. Analyze entrepreneurial skills needed by individuals preparing to enter agriculture and related occupation.

4. Acquire leadership and participant skills necessary for the development of productive citizens in our democratic society.

5. Gain effective social and interpersonal communication skills.

6. Be aware of career opportunities in agriculture and set career objectives.

7. Acquire job-seeking, employability and job retention skills.

8. Advance a career through a program of continuing education and lifelong learning.

9. Apply the basic learning skills in reading, writing, thinking, mathematics, communicating, listening and studying.

10. Recognize the interaction of agriculture with government and economic system at the local, state, national and international levels.

11. Recognize how new technologies impact agriculture and how agriculture impacts the environment.

\section{Challenges of Agricultural Education}

In many developing countries, the public sector used to absorb large majority of Agriculture graduates. This is no longer the case. Agriculture graduates are finding it increasing difficult to be employed; their education in agriculture has not been oriented to the needs of an increasing sophisticated commercial sector. [FAO, 1997] There is therefore the need for agricultural training institutions to adjust to the realities of change as seen in today's world. As with so many aspects of development, education in Africa now faces rapid and often perplexing changes in the environment in which it exists.

Maguire [2000] outlined the following as problems with agricultural education.

1. Isolation of the agricultural University from other parts of the University System.

2. Lack of communication with the employers of the graduates of the University - the labour market.

3. Poor practical skills among graduates

4. Decreased funding as urban focus gathers strength.

5. Weak connection with other parts of the agricultural education system-colleges, vocational, farmer training networks.

6. High unemployment of graduates from the university often due to lack of relevance of curriculum.

7. Failure to attract the best quality students from secondary schools.

8. Inbreeding-teaching and research staff are frequently graduates of the same University or college thereby excluding the entry of new ideas from the wider world of academic and research.

Maguire [2000] further enumerated the changes that could impact on agricultural education to present more challenges to its relevance to include: shift in focus from agriculture to rural development, Globalization, HIVIAIDS, Biotechnology, Urbanization, Information technology.

According to Crowder, Lindley, Bruening and Doron [1999] they categorized the challenges of agricultural education in developing countries into three, thus:

i. Contextual constraint

ii. Changes to curriculum content and emphasis

iii. Changes to educational processes.

From the writer's point of view, these are other challenges of agricultural education as they affect both child and economic development of the nation. 


\subsection{Budgetary and Financial Crisis}

The major source of funding and financial support for agricultural education is the Federal or state government. Agricultural institutions operate on the basis of an annual budget which depends on the number of students enrolled, previous funding levels and government capacity [or willingness to support institutions.]. Agricultural education is expensive. It requires teaching aids and materials, scientific and technical equipment as well as adequately equipped training and experimental farms. Budget cutbacks have also made it difficult to maintain teaching standard due to reduction in recruitment and in staff development programs especially those involving training abroad limited budgeting resources often do not allow teachers to obtain the scientific and technical publications necessary to keep their knowledge current or to up-date research.

\subsection{Weak Synergy in Agricultural Education and Training, Research and Extension relationship}

In many African Countries, agricultural research is generally conducted in research stations and laboratories, the majority of which are not linked with higher institutions of learning, although cases of collaboration between staff exist. Higher institutions of learning have two official aims namely, to conduct basic and applied research and train students on the basis of the research findings to buttress this challenges, Osinem 2008 stated that some lecturers do really carry out research in the University but professional prestige and promotion are frequently seen as more important than solving local agricultural problems. He further stated that the amount of work related to teaching and administrative responsibility often does not allow teaching staff enough time for research. For agricultural institutions to participate fully in research, the role of research should be properly defined in the policies of the institutions including the research relationship to the national agricultural innovation system.

\subsection{Coordination of activities of agricultural education institutions at all levels}

There is no national agency or unit that over sees training at all levels of agricultural activities with institutionalized regulations/policies and practices of programme articulation and credit transfer from one level to the other. For instance, National Board for Technical Education (NBTE) has statutory responsibility for vocational and technical education curricula development and delivery supervision, National Educational Research and Development Council (NERDC) for primary and secondary vocational technical education curriculum, National Commission for College of Education (NCCE) for Colleges of Education while National University Commission (NUC) for universities of agriculture and agricultural faculties of traditional universities.

There is no co-ordination among these bodies. This constitute a serious challenge to agricultural education at all levels because there is no galvanization of research, teaching and promotion of information among teachers and students of agricultural education

\section{Link between Agricultural Education and Human and Economic Development}

Those trained in agriculture become wage earners and turn out to be more useful and contributive citizens. The take up jobs in farming and in non-farming occupations requiring skills and knowledge in agriculture. There are some educational philosophers who believe that unemployment, juvenile delinquency, adult crime, unstable and unsatisfactory political system are as a result of lack of specific training for jobs or occupation (Osinem 2008), so agricultural education should be regarded as "salvation of civilization" it is on this justification that agricultural education in our secondary schools should assume wider meaningful dimension instead of regarding it as a mere school subject. It is important at this point to outline the various levels at which human capital development is carried out through agricultural education.

Agricultural education engages in human capital development among others in the following areas, Agricultural Engineering, Soil and Animal Science, Agronomy Plant Breeding, Pathology and Entomology Agricultural Economics and Policy Making, Teaching, Rural Sociology. Veterinary, Forestry, Horticulture, Genetics, Agro Industries and Business etc. the contributions of specialists in these areas greatly enhance both human and economic development of a nation.

\section{Role of Government as the Way Forward}

Government participation in the direct management of educational institutions varies considerably from one state to the other and country to country. However, overwhelming majority of institutions of agricultural education depend on 
government in terms of objective and organizational structure.

Resources are determined by national policies which also determine the relationship between educations, research and extension. This situation of close dependency on government has led to rigidity in programmes and teaching methods, staff recruitment and mobility. It affects opera rational budgets, teaching resources, technical equipment and out of school activities which are often cut down as national economic problems arise.

In precision terms according to Osinem 2008, the role of government in agricultural education with respect to its challenges includes;

1. Subsidizing agricultural education like in basic practices and research

2. Provision of dynamic learning environment in school so that learning would be sustained.

3. Development of global partnership for the development agricultural education in the country

4. Adequate provision of agricultural facilities that could enhance high standards, experiential learning and livebusinesses that promote entrepreneurship

5. Adequate remuneration and motivation of agriculture education teachers since they are the key to the development of agricultural education in the country

\section{Suggestion}

Government to establish a centre that will be charged with the responsibilities of enhancing interactions and coordinating efforts of agricultural institutions- the schools, research and extension agencies as well as exploring local, national and global linkages to better tackle challenges of agricultural education as the emerge.

\section{Conclusion}

It is hoped that much encouragement will be given to the study of agricultural education in higher institutions for without adequately trained teachers of agriculture; the younger generations may continue to develop apathy for agriculture as a profession. It must be emphasized that the best type of education that can be given to a child is a solid preparation for meeting the challenges ahead. It has a definite role of preparing and equipping the child with skills and competencies that increase the chances of finding a job and that is agricultural education.

\section{References}

Crowther L.V, Lindley W.I. Bruening T.H. and Doron N (1999)Agricultural Education for sustainable Development Challenges for Developing countries in the 21st century. In issues and opportunities for agricultural Education and training in the 1990s and beyond. Rome: FAO.

F.A.O. (1998) Issues and Opportunities for Agricultural Education and Training.A wed publication.

Maguire C.J. (2000) Agricultural Education in Africa: Managing Change. Workshop paper, rural development department, the World Bank, September 4-6.

Obiabuako L.O. (1983) Agricultural Extension strategy for Agricultural Transformation Nsukka University of Nigeria Press

Okorie J.U. (2001) Vocational Industrial Education Bauchi, League of Researchers in Nigeria (LRN).

Osinem E.C. (2008) Managing Agricultural Education and Training Resources, Principles \& Methods, Enugu.Belong International publishers 104 Agbani Roa 